\title{
The influence of the sample preparation of carrots (Daucus Carota L. Neptun) on the antioxidant activity and phenolic compounds
}

\author{
Justina Zykevičiūtè-Laugks ${ }^{\circledR}$, \\ Laima Česoniené ${ }^{1}$, \\ Rasa Karkleliene் $\dot{e}^{2}$ \\ ${ }^{1}$ Aleksandras Stulginskis University, \\ Institute of Environment \\ and Ecology, Studentu 11, \\ LT-53361 Akademija, \\ Kaunas distr., Lithuania \\ ${ }^{2}$ Lithuanian Institute \\ of Horticulture, Babtai, \\ Kaunas distr., Lithuania
}

The growing demand for organic food in the world requires the assessment of the value aspects of food quality, its safety, nutritional content and biological-physiological process.

Fruits and vegetables are good sources of natural antioxidants containing many different antioxidant components. These antioxidants include carotenoids, vitamins, phenolic compounds, flavonoids, dietary glutathione and endogenous metabolites which have been shown to function as singlet and triplet oxygen quenchers, free radical scavengers, peroxide decomposers, enzyme inhibitors, and synergists. Phenolic compounds are found in most fruits and vegetables (Zhang, Hamauzu, 2005). Carrots and their fresh produce (shredded carrots, sliced carrots and carrot juice) may protect humans against certain types of cancer and cardiovascular diseases (Krinsky, Johmson, 2005). Carrots contain mainly hydroxycinnamic acids and derivatives. Among them, chlorogenic acid is a major hydroxycinnamic acid, representing from $42.2 \%$ to $61.8 \%$ of total phenolic compounds (Wang et al., 2006). In addition to the above mentioned compounds found in natural foods, vitamins $\mathrm{C}$ and $\mathrm{E}$, beta-carotene and tocopherol are known to possess antioxidant potential.

The aim of the research was to determine the total antioxidant activity and phenolic compounds which operate as free radical scavengers, peroxide decomposers, enzyme inhibitors and synergists. Carrot breed Neptun was obtained from Lithuanian Institute of Horticulture. Correlations between antioxidant activity and phenolic compounds were determined by using three drying methods (carrots were sliced and dried in desiccator at $+40{ }^{\circ} \mathrm{C}$ and lyophilised under vacuum conditions (freezedried) by $-72{ }^{\circ} \mathrm{C}$ for sample preparation. Antioxidant activity was determined by using DPPH radicals spectrophotometrically. The influence of drying method was not significant $\mathrm{p}>0.05$, but solvent concentration showed significant correlation with antioxidant activity and phenolic compound ( $\mathrm{p}<0.05)$. Among the weight of raw material and various ratios of methanolic extracts, significantly the best antioxidant activity was shown by $0.5 \mathrm{~g}$ and $75 \%$ of sliced desiccated, freeze-dried and pressed desiccated samples The total phenolic content of carrot material

*Corresponding author. E-mail: zyklaujus@gmail.com 
investigated during this research varied from 0.07 to $0.31 \mathrm{mg} / \mathrm{ml}$ of the methanolic carrot extracts and from 1.51 to $7.01 \mathrm{mg} / \mathrm{g}$ of dry carrot content, expressed by gallic acid equivalent (GAE). The time effect for DPPH scavenging was significant until $30 \mathrm{~min}(\mathrm{p}<0.05)$. If the reaction achieved a plato effect (balance), approx. $80 \%$ of antioxidant activity, the time effect was not significant $(\mathrm{p}>0.05)$.

Key words: Daucus carota L. Neptun, phenolics, antioxidant activity, methanolic extracts

\section{INTRODUCTION}

The presence of phenolic compounds in carrots contributes to their sensory qualities, like colour (Zhang et al., 2004), bitterness (Kreutzmann et al., 2008), or aroma (Naczk, Shahidi, 2003). Therefore, the response of phenolic compounds could be used as a good indicator to evaluate the vegetables quality during processing and storage. The quality of vegetables mostly depends on the components accumulated in fresh matrix, peel and cortex (Goncalves et al., 2010). Therefore it is very important to precisely estimate the quality of carrots. There were determined relative levels of antioxidant activity in several of carrots consisting of a variety of vegetable families, selected on the basis of their widespread use in traditional consumption via scavenging of 2,2-diphenyl-2-picryl hydrazyl hydrate (DPPH) radical determined spectrophotometrically. A number of carrot species with appreciable levels of antioxidant activity against the DPPH radical were identified as potential sources of free radical scavenging compounds (Puodžiūnienè et al., 2005).

\section{Active compounds}

Fruits and vegetables are good sources of natural antioxidants containing many different antioxidant components. These antioxidants include carotenoids, vitamins, phenolic compounds, flavonoids, dietary glutathione and endogenous metabolites and have been shown to function as singlet and triplet oxygen quenchers, free radical scavengers, peroxide decomposers, enzyme inhibitors, and synergists (Larson, 1988). Phenolic compounds are found in most fruits and vegetables. Carrots contain mainly hydroxycinnamic acids and derivatives. Among them, chlorogenic acid is a major hydroxycinnamic acid, representing from $42.2 \%$ to $61.8 \%$ of total phenolic compounds (Wang et al., 2006). In addition to the above mentioned compounds found in natural foods, vitamins $\mathrm{C}$ and $\mathrm{E}$, beta-carotene and tocopherol are known to possess antioxidant potential (Prior, 2003).

Carrot breed (Daucus carota L. Neptun) was chosen for the experiment from Lithuanian Institute of Horticulture, Babtai, Lithuania. Correlations between some of radical scavenging parameters were determined. 
The aim of the research was to evaluate the drying method and sample preparation to determine antioxidant activity (DPPH) and total phenolic compounds. The task was to evaluate sample preparation of carrots by using three drying methods and different ratio $(75 \%$ and $100 \%$ ) of methanol for carrot samples extractions (freeze-dried under vacuum condition at $-72{ }^{\circ} \mathrm{C}$, the second - sliced with blender and the third - pressed carrots by the juice press, then desiccated in the fruit and vegetable desiccator at $+40^{\circ} \mathrm{C}$.

\section{MATERIALS AND METHODS}

\section{Materials}

Fresh carrots (Daucus carota L. Neptun) were provided by Lithuanian Institute of Horticulture, Babtai, Lithuania. Methanol $\left(\mathrm{CH}_{3} \mathrm{OH}\right)$ was of analytical grade (SigmaAldrich, Germany), 2,2-diphenyl-2-picrylhydrazyl hydrate (DPPH) was from SigmaAldrich (Germany). Bidistilled water was used for the experiments, (2N) Folin-Ciocalteu reagent was obtained from Sigma (USA), $\mathrm{Na}_{2} \mathrm{CO}_{3}$ p.a. (Chempur, Poland).

\section{Preparation of carrot extracts in methanol}

Sample preparation is the first crucial step in the analysis. In this research, sample preparation is similar to the preparation of medicinal herbs. Fresh carrots were sliced by "BRAUN" blender (Germany) and dried at $+40{ }^{\circ} \mathrm{C}$ in desiccator (Scarlett SC-420), half of them were freezedried under vacuum conditions at $-72{ }^{\circ} \mathrm{C}$ up to $72 \mathrm{~h}$ (Scanvac coolSafe ${ }^{\mathrm{m}} 55-9$, UK) and the third drying method involved carrots pressed by juice press Phillipps (Germany) and dried at $+40{ }^{\circ} \mathrm{C}$ in desiccator (Scarlett SC-420). Twelve liquid maceration procedures were applied by shaking flasks with $0.5 \mathrm{~g}$ and $0.25 \mathrm{~g}$ of finely grounded dried carrots and different percent of solvent $\left(75 \%\right.$ and $\left.100 \% \mathrm{CH}_{3} \mathrm{OH}\right)$ in a GFL3017 shaking machine. Extraction step lasted $1 \mathrm{~h}$.
Evaluation of antioxidant activity by means of DPPH radical scavenging assay

Among chemical methods applied to determine the antioxidant activity of a compound, DPPH. (2,2-diphenyl-1-picrylhydrazyl) is one of the most frequently used methods because it is practical, fast and stable (Espin et al., 2000). Radical scavenging activity of methanolic carrot extracts against stable DPPH was determined spectrophotometrically. When DPPH reacts with an antioxidant compound, which can donate hydrogen, it is reduced. The changes in colour (from deep violet to light yellow) were measured at $515 \mathrm{~nm}$ on UV/visible light spectrophotometer T70+UV/VIS Spectrometer PG Instruments Ltd. Radical scavenging activity of extracts was measured by a slightly modified method of Brand-Williams et al., 1995 as described below. The solution of DPPH in methanol was prepared daily, prior to UV measurements. $3 \mathrm{ml}$ of this solution were mixed with $77 \mu$ lof extract solution in $1 \mathrm{~cm}$ path length cuvettes. The samples were kept in the dark for $15 \mathrm{~min}$ at ambient temperature and then the decrease in absorption was measured. Absorption of blank sample containing the adequate amount of methanol and $\mathrm{DPPH}$ solution was prepared and measured daily. The experiment was carried out in triplicate. Radical scavenging activity was calculated by the following formula:

$$
\% \text { Inhibition }=\frac{\mathrm{AB}-\mathrm{AA}}{\mathrm{AB}} * 100 \%
$$

where: $\mathrm{AB}$ - absorption of blank sample $(\mathrm{t}=0 \mathrm{~min}) ; \mathrm{AA}-$ absorption of tested extract solution $(\mathrm{t}=15 \mathrm{~min}, \mathrm{t}=30 \mathrm{~min}, \mathrm{t}=45 \mathrm{~min})$. All assessments were performed in triplicate.

The content of phenolic compounds was determined by Folin-Ciocalteu colorimetric method (Folin-Ciocalteu, 1927; Wu Cu et al., 2007). The total phenolic content in carrot extracts was analyzed spectrophotometrically on UV/visible light spectrophotometer T70+UV/VIS Spectrometer PG Instruments Ltd using a modification of Folin-Ciocalteu 
colorimetric method (Folin-Ciocalteu 1927; Singleton, Rossi, 1965). This method consists of determining the total polyphenol content through oxidation of phenolic compounds using a mix of phosphotungstic and phosphomolybdic acids in base medium, producing blue acids of tungsten and molybdenum. Absorbance of these acids was then read at $765 \mathrm{~nm}$ (Folin, Ciocalteu, 1927). The results were expressed in mg gallic acid / $100 \mathrm{~mL}$. Each assay was performed in triplicate. $0.05 \mathrm{~mL}$ of methanolic carrot extracts were mixed with $1.25 \mathrm{~mL}$ of doubledistilled water, followed by the addition of $0.05 \mathrm{~mL}(2 \mathrm{~N})$ Folin-Ciocalteu reagent, and then well mixed. After being allowed to stand for $6 \mathrm{~min} 0.25 \mathrm{~mL}$ of $20 \%$ sodium carbonate solution was added. The colour was developed by keeping at room temperature for $30 \mathrm{~min}$, and the absorbance measured at $760 \mathrm{~nm}$ using UV visible spectrophotometer. The measurement was compared to a standard curve prepared using gallic acid solution and expressed as the mean, in $\mathrm{mg}$, calculated from equation $y=0.0931 x+0.0134\left(R^{2}=0.9616\right)$ of gallic acid equivalent (GAE) per g of carrot dry material from triplicate extracts (Prior, 2003).

\section{Statistical analysis}

Data was analysed by SPSS statistic program (Portable_SPSS_v19.0.0.329), the disperse analysis method, Spearman correlation was obtained between antioxidant activity and phenolic compounds, time effect for antioxidant activity, dry mass of carrots content, influence of solvent percentage and, finally, the drying methods for carrots. Statistical analysis was performed using correlation matrixes test and $\mathrm{p}<0.05$ was used as the level of significance: one-way analysis of variance (ANOVA) followed by Tuckey's post test were used to assess significant differences $(\mathrm{p}<0.05)$ in the same groups. The test of homogeneity was $\mathrm{p}<0.05$ value. The assays of total antioxidant activity, amount of phenolic compounds were carried out in triplicate. The values ( $\%$ and $\mathrm{mg} / \mathrm{g}$ ) were presented as means \pm standard deviation (SD) in Figs. 1-2, correspondingly.

\section{RESULTS AND DISCUSSION}

Determination of antioxidant activity and phenolic compounds by various sample preparations of carrot breed Neptun is described

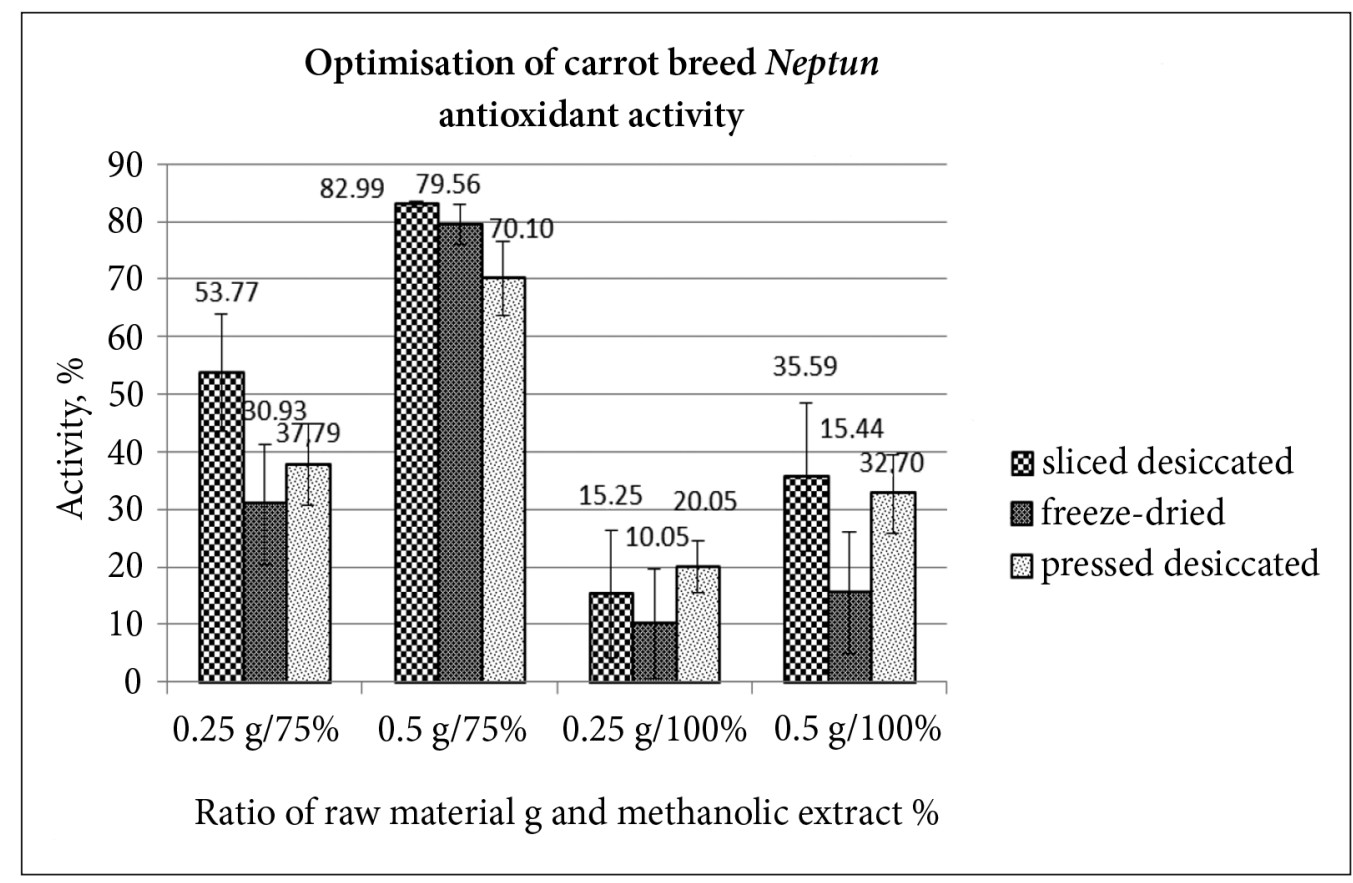

Fig. 1. DPPH radical scavenger activity, $\%$ 


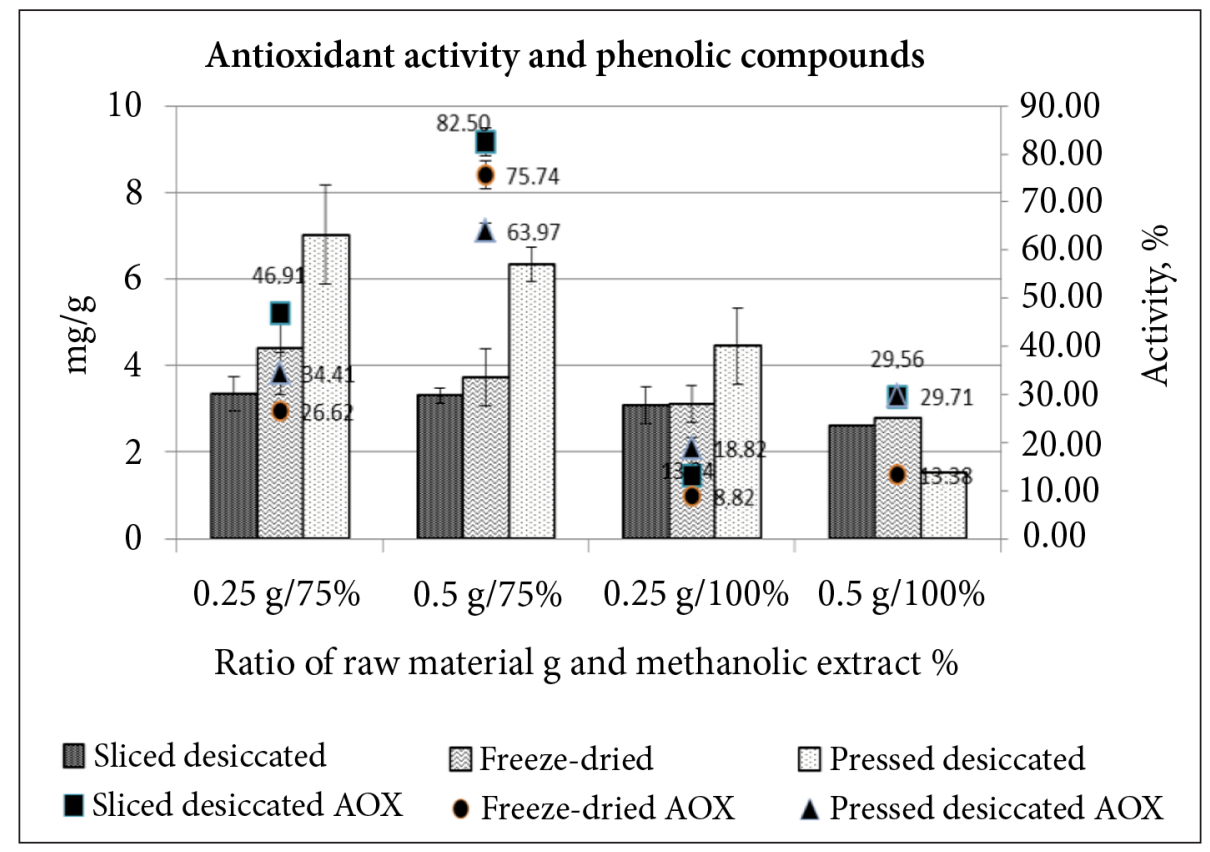

Fig. 2. Content of phenolic compounds, using gallic acid as a standard and expressed as $\mathrm{mg} / \mathrm{g}$ of gallic acid equivalent (GAE) in dry carrot material (Folin-Ciocalteu method). Antioxidant activity \% is shown as a point of AOX

below. The sample preparation is a crucial step of biocompounds determination in the plant analysis. Sample preparation for carrots is similar to that as for medicinal herbs. Methanolic extract was obtained using $0.5 \mathrm{~g}$ and $0.25 \mathrm{~g}$ of dry carrot material and $10 \mathrm{ml} \mathrm{75 \%}$ and $100 \%$ of methanol. Results are shown in Fig. 1.

Antioxidant activity was determined using DPPH radicals. Influence of drying method (sliced and dried in desiccator at $+40{ }^{\circ} \mathrm{C}$ or lyophilised under vacuum conditions (freezedried) at $-72{ }^{\circ} \mathrm{C}$ ) was not significant $\mathrm{p}>0.05$, but solvent concentration showed significant correlation with antioxidant activity and phenolic compound $(\mathrm{p}<0.05)$. Among the weight of raw material and various ratios of methanolic extracts, significantly the best antioxidant activity was shown by $0.5 \mathrm{~g}$ and $75 \%$ of sliced desiccated, freeze-dried and pressed desiccated samples (Fig. 1). According to literature, phenolic compounds are mostly responsible and correlate with antioxidant activity. Polarity of solvent has great influence on the extracted compounds and it depends on the dielectric constant of solvent mixture.
"Solvent(s)" means a substance or substances in which various other substances may be fully or partially dissolved. Preferred solvents include aqueous solvents, and solvents having a dielectric constant less than that of water. The solvents water, methanol, ethanol, 1-propanol, 1-butanol, and acetic acid are polar protic solvents having a hydrogen atom attached to an electronegative atom, typically oxygen. Solvents having a dielectric constant less than that of water are particularly useful in the formation of the inventive complexes. In literature, dielectric constant of water is 80 and that of methanol - 33 (Guittard et al., 2005).

The total phenolic content of carrot material investigated varied from 0.07 to $0.31 \mathrm{mg} / \mathrm{ml}$ of the methanolic carrot extracts and from 1.51 to $7.01 \mathrm{mg} / \mathrm{g}$ of dry carrot content expressed by gallic acid equivalent (GAE). Antioxidant activity $\%$ is shown as a point of AOX. Extracts of $0.25 \mathrm{~g}$ of pressed carrots showed up to $7.01 \mathrm{mg} / \mathrm{g}$ phenolic content in dry carrot material with $75 \%$ of methanol solvent. Ratio of solvent was significant for pressed carrots $(\mathrm{p}<0.05)$. The amount of phenolic compounds showed mean correlation $\left(\mathrm{R}^{2}=0.608\right)$ to the 


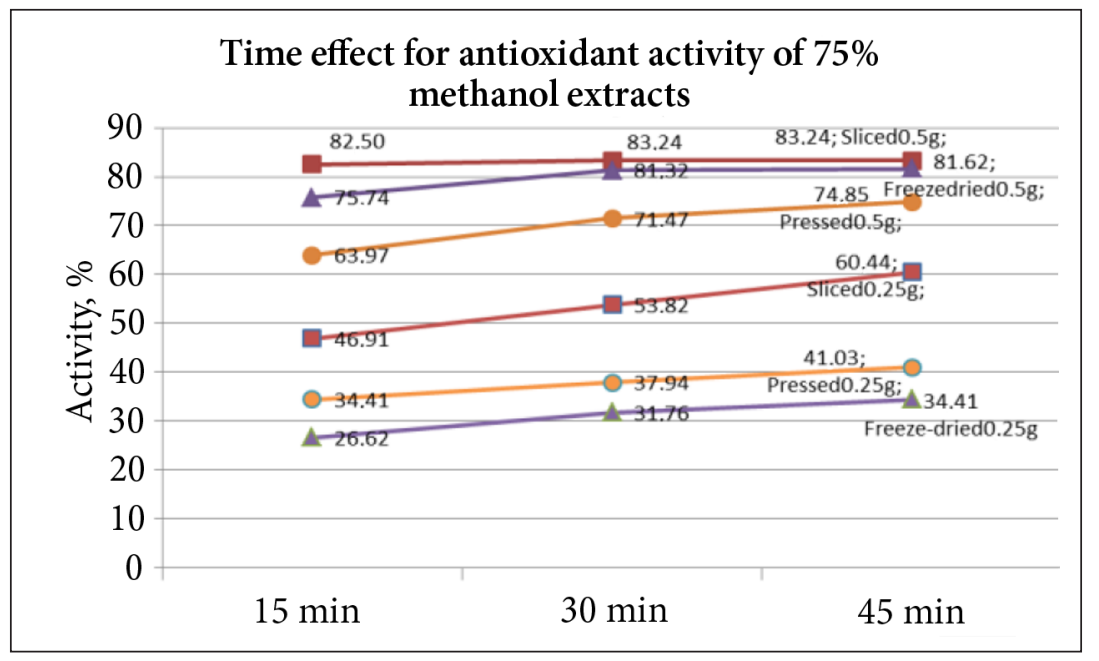

Fig. 3. The time impact on the dynamic of the antioxidant activity (by 75\% methanolic extracts)

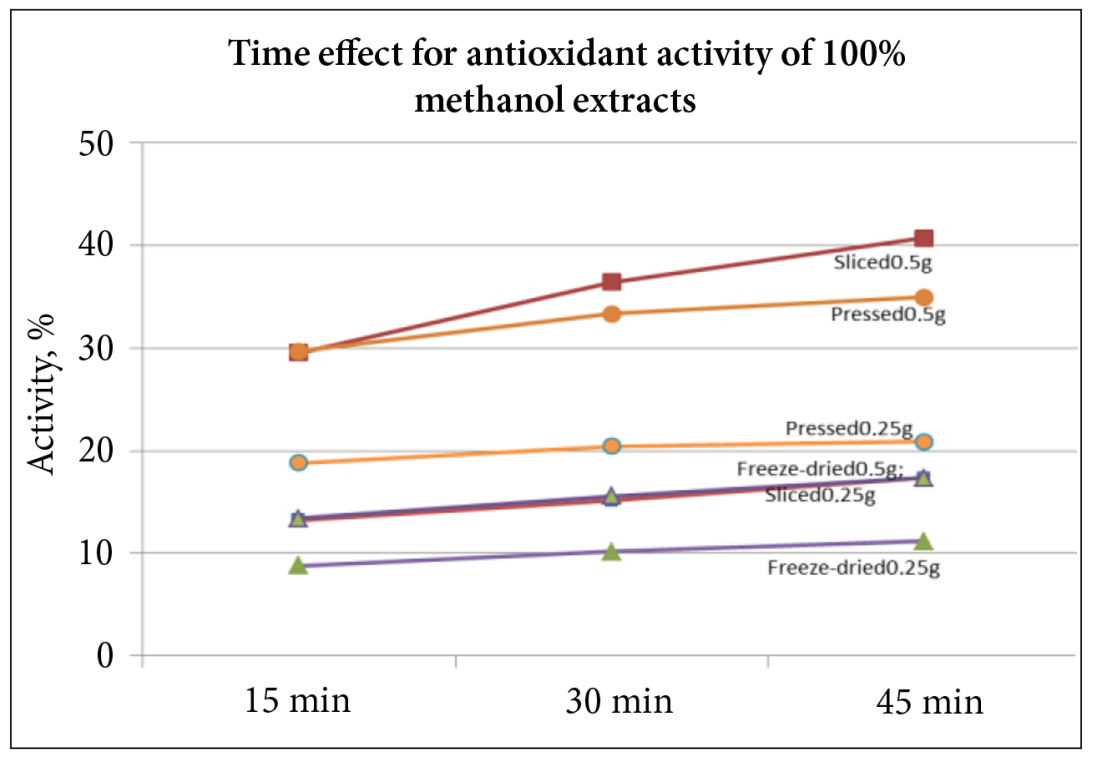

Fig. 4. Dynamic of AOX activity in 100\% extracts

antioxidant activity. Correlation is significant at 0.05 level (2-tailed).

The dynamic reaction of antioxidant activity for the time period was evaluated and absorbance was read at $515 \mathrm{~nm}$ at different time intervals until the reaction reached stability. According to literature, most often the value of absorbance is recorded after $15 \mathrm{~min}$. The results are shown in Fig. 3.

Significant time effect was until $30 \mathrm{~min}$, $\mathrm{p}<0.05$. If the reaction achieved a plato effect (balance), about $80 \%$ of antioxidant activity (sliced carrots $0.5 \mathrm{~g}$ ), the time effect was not significant $(\mathrm{p}>0.05)$. The best result until the reaction reached stability was achieved using $0.5 \mathrm{~g}$ of carrot material with $75 \%$ of solvent.

Carrot extracts made with $100 \%$ methanol have significant balance, if $0.25 \mathrm{~g}$ material was taken. In most cases the time effect was significant by sliced $0.5 \mathrm{~g}$ and pressed $0.5 \mathrm{~g}$ carrots, $\mathrm{p}<0.05$, until $45 \mathrm{~min}$, but no significant change was for the remaining $\mathrm{p}>0.6$. The reaction achieved a plato effect (balance) approx. $10-20 \%$ of antioxidant activity, the time effect was not significant $(\mathrm{p}>0.05)$ by pressed $0.25 \mathrm{~g}$, freeze-dried $0.25 \mathrm{~g}$ and $0.5 \mathrm{~g}$, and sliced 
$0.25 \mathrm{~g}$. In this case, no changes in reaction dynamics were noticed by low antioxidant activity, but over $10 \%$ changes of antioxidant activity values were noticed in case of the sliced $0.5 \mathrm{~g}$ and pressed $0.5 \mathrm{~g}$ carrots. According to literature, it depends on dissolved substances in solvent from carrots.

\section{CONCLUSIONS}

Antioxidant activity was determined using DPPH radicals. Influence of drying method (sliced and dried in desiccator at $+40{ }^{\circ} \mathrm{C}$ or lyophilised under vacuum conditions (freezedried) at $-72^{\circ} \mathrm{C}$ ) was not significant $\mathrm{p}>0.05$, but solvent concentration showed significant correlation with antioxidant activity and phenolic compound $(\mathrm{p}<0.05)$. Among the weight of raw dried material and the various ratios of methanolic extracts, significantly the best antioxidant activity was shown by $0.5 \mathrm{~g}$ and $75 \%$ of sliced desiccated, freeze-dried and pressed desiccated samples. For the next step of sample preparation, extraction with $75 \%$ of solvent and $0.5 \mathrm{~g}$ of dry material of carrots would be preferable. Drying methods had no significant value for antioxidant activity $(\mathrm{p}>0.05)$, but were significant for phenolic compounds $(\mathrm{p}<0.05)$.

\section{ACKNOWLEDGEMENT}

Carrot samples provided by Lithuanian Institute of Horticulture in Babtai are acknowledged.

Received 25 May 2013

Accepted 30 June 2013

\section{References}

1. Brand-Williams W, Cuvelier M, Berset C. Use of a free radical method to evaluate antioxidant activity. Lebensmittel-Wissenschaft-undTechnologie 1995; 28: 25-30.

2. Zhang D, Yasunori H. Phenolic compounds and their antioxidant properties in different tissues of carrots (Daucus carota). J Food Agric Envir (JFAE) 2004; 2(1): 95-100.

3. Goncalves EM, Pinheiro J, Abreu M, Brandao TRS, Silva CLM. Carrot (Daucus carota L.) peroxidase inactivation, phenolic content and physical changes kinetics due to blanching. J Food Engin 2010; 97: 574-81.

4. Genè Puodžiūnienè, Valdimaras Janulis, Arvydas Milašius, Vytautas Budnikas. Medicina, Kaunas; 2005: 4(6).

5. George V Guittard, Stephen Hwang, Patrick SL Wong, Dong Yan. Administration of levodopa and carbidopa WO 2005041924A2 (http://www.google.com/patents/WO20050 $41924 \mathrm{~A} 2$ ?hl=lt\&cl=en)

6. Espin JC, Soler-Rivas C, Wichers HJ; Garcia-Viguera C. Anthocyanin-based natural colorants: A new source of antiradical activity for foodstuff. J Agric Food Chem 2000; 48: 1588-92.

7. Folin C, Ciocalteu V. Tyrosine and tryptophan determination in protein. J Biol Chem 1927; 73: 627-50.

8. Krinsky NI, Johmson EJ. Carotenoid actions and their relation to health and diseases. Molec Asp Medic 2005; 26: 459-516.

9. Kreutzmann S, Christensen LP, Edelenbos M. Investigation of bitterness in carrots (Daucus carota L.) based on quantitative chemical and sensory analyses. Lebensmittel-Wissenschaft und-Technologie 2008; 41(2): 193-205.

10. Larson RA. The antioxidants of higher plants. Phytochem 1988; 4: 969-78.

11. Naczk M, Shahidi F. Phenolic compounds in plant foods: chemistry and health benefits. Nutraceut Food 2003; 8(2): 200-18.

12. Prior RL. Fruit and vegetables in the prevention of cellular oxidative damage. Am J Clin Nutr 2003; 78: 570S-8S.

13. Singleton VL, Rossi JR. Colorimetry of total phenolics with phosphomolybdic-phosphotungstic acid. Am J En Vitic 1965; 16: 144-58.

14. Wang H, Hu X, Chem F, Wu J, Zhang Z, Liao X., Wang Z. Kinetics analysis of nonenzymatic 
browning in carrot juice concentrate during storame. Eur Food Res Techn 2006; 223: 282-9.

15. Zhang D, Hamauzu Y. Phenolic compounds and their antioxidant properties in different tissues of carrots (Daucus carota L.). Food Agric Envir 2004; 2(1): 95-100.

16. Wang H., Cao G, Prior RL. Total antioxidant capacity of fruits. J Agric Food Chem 1996; 44: 701-5.

17. Wu Cu, Murthy HN, Hahn EJ, Paek KY. Improved production of caffeic acid derivatives in suspension cultures of Echinacea purpurea by medium replenishment strategy. 2007 Aug; 30(8): 945-9. PMID: 17879746 [PubMed indexed for MEDLINE].

Justina Zykevičiūtè-Laugks, Laima Česonienè, Rasa Karklelienè

IPRASTINIŲ MORKŲ (DAUCUS CAROTA L.) BANDINIŲ DŽIOVINIMO POVEIKIS ANTIOKSIDACINIAM AKTYVUMUI IR FENOLINIŲ JUNGINIŲ KIEKIUI

Santrauka

Skirtingomis ekstrakcijos sąlygomis - derinant sausos masès kieki ir tirpiklio procentini santykį, atliekant reakcijas su laisvuoju radikalu DPPH bei matuojant spektrofotometriškai ties $515 \mathrm{~nm}$ bangos ilgiu - siekta nustatyti antioksidacinị 'Neptun' morkų veislès aktyvumą. Šioje morkų veislejje rasti fenolinių junginių kiekiai svyravo tarp 0,07 ir 0,31 mg/ml metanolio ekstrakto ir tarp 1,51 ir $7,1 \mathrm{mg} / \mathrm{g}$ sausos morkų masès pagal galo rūgšties ekvivalentus (FolinCiocalteu modifikuotas metodas). Didžiausias antioksidacinis aktyvumas - $82 \%$ nustatytas sukapotų ir vaisių džiovyklèje išdžiovintų morkų, kai 0,5 g sausos morkų žaliavos ekstrahuota $75 \%$ metanoliu. Mažiausias aktyvumas - apie $8 \%$ gautas ekstrahuojant 0,25 g sausos morkų žaliavos $100 \%$ metanolio tirpikliu. Išmatavus antioksidacinio aktyvumo kaitą laiko atžvilgiu kas $15 \mathrm{~min}$., reikšmingi skirtumai gauti iki 45min. taikant $100 \%$ metanolio ekstrakciją 0,5 g kapotai sausai medžiagai ( $p>0,05)$. Su $75 \%$ metanolio ekstrakcija gauti skir- tumai nereikšmingi laiko atžvilgiu. 0,5 g kapotose morkose, džiovintose vaisių džiovykleje, pasiekus $80 \%$ aktyvumą, reakcija pasiekdavo pusiausvyrą. Džiovinimo poveikis antioksidaciniam aktyvumui buvo nedidelis ( $p>0,05)$, bet reikšmingas bendram fenolinių junginių kiekiui ( $\mathrm{p}<0,05)$.

Raktažodžiai: Daucus carota L. 'Neptun', fenoliniai junginiai, antioksidacinis aktyvumas, metanolio ekstraktas 